\title{
Keep it short and sweet
}

\author{
Ian A. Makey, MD, ${ }^{a}$ and Scott B. Johnson, $\mathrm{MD}^{\mathrm{b}}$
}

\author{
From the ${ }^{\mathrm{a}}$ Department of Cardiothoracic Surgery, Mayo Clinic, Jacksonville, Fla; and ${ }^{\mathrm{b}}$ Department of Cardiotho- \\ racic Surgery, UT Health San Antonio, San Antonio, Tex. \\ Disclosures: Authors have nothing to disclose with regard to commercial support. \\ Received for publication March 25, 2018; accepted for publication March 28, 2018; available ahead of print May \\ $1,2018$. \\ Address for reprints: Scott B. Johnson, MD, University of Texas, Health Science Center at San Antonio, Depart- \\ ment of Cardiothoracic Surgery, 7703 Floyd Curl Dr, MC 7841, San Antonio, TX 78284-7841 (E-mail: \\ johnsons@uthscsa.edu). \\ J Thorac Cardiovasc Surg 2018;156:e33 \\ $0022-5223 / \$ 36.00$ \\ Copyright (C 2018 by The American Association for Thoracic Surgery \\ https://doi.org/10.1016/j.jtcvs.2018.03.121
}

There are numerous risk factors for bronchial dehiscence after lung transplantation, including primary graft dysfunction, acute rejection, infection, technical error, and prolonged ventilation. Ischemia probably contributes to some degree in most-if not all-cases. In 1987, Cooper and colleagues ${ }^{1}$ reported on the first successful lung transplants, in which they wrapped the bronchial anastomosis with omentum. One prospective, randomized trial, however, found no benefit from wrapping the bronchial anastomosis with vascularized tissue. ${ }^{2}$ Despite evidence showing little to no benefit, buttressing of many types of anastomoses with vascularized tissue is still commonly performed. Wrapping with a vascularized flap may help to contain air leaks and prevent fistula formation, but it is unlikely to reduce ischemia. One factor most certainly related to ischemia is donor bronchus length - the longer the length, the more likely the presence of ischemia.

The history of lung transplantation illustrates the progressive reduction in length of the donor bronchus. En bloc double-lung transplants are no longer preferred because of the frequency of tracheal anastomotic complications. ${ }^{3}$ In the early experience with single-lung transplants, dehiscence of the bronchial anastomosis was the cause of most deaths. In the 1990s, the rate of airway anastomotic complications was $10 \%$ to $20 \% .{ }^{4}$ More recently, 2 single-center studies demonstrated a drop in airway anastomotic complications after shortening the donor bronchus to 1 bronchial ring or less, as opposed to the more traditional 1 to 2 rings. ${ }^{5,6}$ Although one can never be sure of the exact cause of bronchial dehiscence, reducing ischemia certainly has a physiologic rationale. Surgical technique also undoubtedly plays a role, although the "best" type of bronchial anastomosis remains unknown. Bronchial size mismatch might require telescoping, even though end-toend is preferred.

\section{References} Surg. 1987;93:173-81. ahead of print].

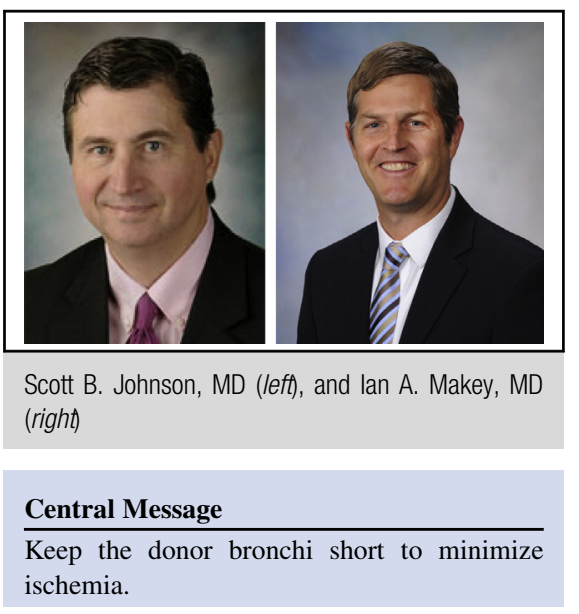

See Article page e29.

Krähenbühl and colleagues ${ }^{7}$ are to be commended for a nice "save" from a devastating complication after lung transplantation. In their revisional surgery, Krähenbühl and colleagues ${ }^{7}$ necessarily shortened their donor bronchi by at least $2 \mathrm{~mm}$, which probably aided in healing. The question we will continue to ask is this: How do we prevent this complication from happening in the first place? One answer is clear. Keep it short and sweet.

1. Cooper JD, Pearson FG, Patterson GA, Todd TR, Ginsberg RJ, Goldberg M, et al Technique of successful lung transplantation in humans. J Thorac Cardiovasc

2. Khaghani A, Tadjkarimi S, al-Kattan K, Banner N, Daly R, Theodoropoulos S, et al. Wrapping the anastomosis with omentum or an internal mammary artery pedicle does not improve bronchial healing after single lung transplantation: results of a randomized clinical trial. J Heart Lung Transplant. 1994;13:767-73.

3. Cypel M, Waddell T, Keshavjee S. Airway complications after lung transplantation. UpToDate. Available at: https://www.uptodate.com/contents/airwaycomplications-after-lung-transplantation. Accessed November 28, 2017.

4. Daly RC, McGregor CG. Surgical issues in lung transplantation: options, donor selection, graft preservation, and airway healing. Mayo Clin Proc. 1997;72:79-84.

5. van Berkel V, Guthrie TJ, Puri V, Krupnick AS, Kreisel D, Patterson GA, et al Impact of anastomotic techniques on airway complications after lung transplant. Ann Thorac Surg. 2011;92:316-20; discussion 320-1.

6. FitzSullivan E, Gries CJ, Phelan P, Farjah F, Gilbert E, Keech JC, et al. Reduction in airway complications after lung transplantation with novel anastomotic technique. Ann Thorac Surg. 2011;92:309-15.

7. Krahenbuhl SM, Gonzalez M, Aubert JD, Tamm M, Ris HB, Krueger T, et al. Management of bilateral necrotizing bronchial dehiscence after a double lung transplantation. J Thorac Cardiovasc Surg. March 30, 2018 [Epub 